\title{
Sustainable forest management as a basis for economic security
}

\author{
Galina Butko \\ Ural State University of Economics, 8 Marta / Narodnoy Voli St., 62/45, 620144 Ekaterinburg, \\ Russia
}

\begin{abstract}
The paper discusses the prospects for the future of the economy and the possibility of its development within national projects. We focus our attention on the relevance of sustainable territory development and environmental protection. The trend of today is green economy and therefore, green energy and green technologies. Ensuring economic security is considered from the perspective of sustainability. The conclusions made are related to the increase of competitiveness by means of innovative development. Sustainable management of forest ecosystems suggests long-term forest preservation through direct and indirect financing of innovative activities. The directions of stable and sustainable economic development are highlighted, the implementation of the scientific research results and applied developments in the economic turnover being among the most promising ones. A method for constructing an integral index of sustainable forest management by using a group of indicators is proposed. 6 macro-indicators with corresponding micro-indicators reflecting the process of sustainable forest management were taken into account. Individual indicators are interpreted as concurrent ecological and economic, ecological and socio-economic, socio-ecological. It is important to form and evaluate the construction of an aggregated indicator. Attention is focused on the use of innovations that are competitive in the domestic and world markets of forestry products. The methods of innovation management are based on the creation of territorial-industrial forest clusters with the rational use of natural resource potential being taken into account.
\end{abstract}

\section{Introduction}

In Russia, the largest forest power, market relations began to manifest themselves, bypassing the stage of partnerships. The year 1990 turned out to be a turning point in the process, although, ideally, entrepreneurial activity should be constantly monitored by the state.

The rapid transition from a planned economy to a market economy was spontaneous, without proper reflection. Unlike the oil, gas, and mining industry, forestry and the whole timber industry complex did not receive any support from the state. Most important, the negative consequences of the nineties for the forestry sector can be felt even today.

The future of the economy is being formed under national projects. Sustainable territory development and environmental protection are of great importance. The trend of today is 
green economy and therefore, green energy and green technologies. The purpose of the organization's management is to search for priority development directions from the perspective of sustainable development. Improving tools and methods for managing innovative activities in small and medium-sized businesses is of primary importance. This approach is based on the creation of territorial-production forest clusters, the rational use of the natural resource base of forestry being taken into account. Electronic technologies implemented during the COVID 19 pandemic, as well as a cluster approach to innovative development, are meant to ensure efficiency and integration of economic processes.

\section{Materials and Methods}

One of the indicators of the region's economic security is sustainable forest management. Currently, much attention is paid to the competitiveness of the region's economy from the perspective of its economic security. The competitiveness of the region's economy is both a prerequisite and a consequence of ensuring economic security.

Systematic, situational and dynamic approaches, as well as methods for assessing the effectiveness of management decisions, methods of comparison, generalization, analogies, which can be used at specialized forestry enterprises, are adopted as a methodological toolkit.

\section{Results and Discussion}

According to professor A.P. Petrov's approach and given his findings [1, 2], a most rational direction in increasing competitiveness from the standpoint of sustainable forest management can be provided on the basis of innovative activity study. The keystone of the problem is the economic theory and practice of using innovation resources at the input of the process and the effective parameters of economic development: the theory of accumulation, the theory of reproduction, the theory of economic growth, and the theory of economic trends. In S.V. Makar's study, an assessment of the forest potential effectiveness is provided and a methodological framework for constructing an integral index of forest potential sustainable development is established. Separate indicators are interpreted as "mixed ecological and economic, ecological and socio-economic, socio-ecological" [11, p.13]. Yet, such experts in the field as S. Medvedev and S. Krylova [12, 13] hold a different view point. It is important in both directions to focus on the construction of an aggregated indicator. For example, the economic aspect brings together economic structure, production and consumption. With this approach, it is possible to create heterogeneous blocks of indicators based on the step-by-step integration of individual indices.

Despite the increased interest in innovation processes assessment, which is demonstrated by the use of various methods, the main tools for managing innovative activities in small businesses of the forestry sector in the regions of the country are not sufficiently developed.

Currently, more than half of all forests in the Russian Federation grow on permafrost soils (Siberia and the Far East), which determines their low productivity. Therefore, a small share of the forested area is of interest for forest management. At the same time, a significant part of these forests is located in the European North and Western Siberia. The priority of the forestry sector innovative development in the Ural region's economy is a sustainable, stable supply of all the population segments as well as businesses with both wood and non-wood raw materials. The provision of protective and recreational services, ecological balance and preservation of forest biodiversity are relevant. In addition to organizational, managerial, product innovations, lean innovations also take place. Despite 
their highly controversial nature, we should note that the forest benefits are included in the block of innovative transformations that take into account lean innovations, too.

The main thing from the perspective of the Concept of Sustainable Forest Management and Sustainable Development is the creation of favorable macroeconomic conditions in the region for the development of entrepreneurial initiative and transition to an innovative economy.

In order to overcome the dependence on timber raw materials, it is necessary to decrease the export of unprocessed round wood raw materials from the region.

To ensure stable sustainable economic development, it is envisaged to:

- implement the results of scientific research and applied developments, as well as intellectual property in the economic turnover;

- use the innovations that are competitive in the domestic and world forestry markets;

- consolidate scientists, experts and entrepreneurs of the forestry sector;

- concentrate resources and ensure their interchangeability;

- raise the level of awareness among managing bodies, businesses and organizations of the scientific and technical sphere;

- improve digital methods for initial information processing,

- attract intellectual resources into the production turnover,

- manufacture competitive products for external consumers.

Thus, to ensure sustainable economic development, it is necessary to achieve the main objective - to form at the regional level a self-sufficient integral innovation system, capable of reproducing and self-developing.

K.G. Skripkin [3] gives the following definitions to the criteria for sustainable forest management:

1. Preserving and maintaining the productive forest capacity - 9 indicators.

2. Maintaining proper sanitary conditions and forest viability - 4 indicators.

3. Preserving and maintaining forest functions -3 indicators.

4. Preserving and maintaining forest biodiversity and its contribution to global ecological cycles -8 indicators.

5. Maintaining forests' socio-economic functions - 7 indicators.

6. Forest policy instruments for forest preservation and sustainable management - 5 indicators.

Maintaining appropriate conditions for forest ecosystems, which is the basis for sustainable forest management, is important both at the macro and micro levels from the perspective of biological diversity and forest productivity. Sustainable management of forest ecosystems suggests long-term forest preservation. At the same time, it is necessary to establish growth indicators.

In the forestry sector of the economy, we should take into account that the main issues of the current period relate not to the resource accumulation, but to the resource direct use. Most important, forestry is the basic branch of the entire timber industry of the Russian economy.

Some experts give a global focus to the regional aspect of the problem [4]. A number of scholars suggest that innovation policy promotion should become a priority direction in the framework of sustainable development [5].

The practical implementation of the concept of sustainable forest management, the main principles of which were determined at the United Nations Conference on Environment and Development (Rio de Janeiro, 1992), and in documents of the Helsinki, Kyoto and Montreal processes, confirms the need to preserve existing forest resources, as well as to improve their condition.

The Government documents from the Ministry of Natural Resources and Environment of the Russian Federation confirm the relevance of the problem, too [6, 7]. 
The issue of innovative activities financing is of particular importance. We distinguish between direct and indirect financing methods. Direct financing of innovative activities is provided from special off-budget funds and budgetary funds, as well as through compensation for the interest rate of commercial banks and in the form of partial tax payments of certain participants in innovative activities. Direct methods of financing are expedient at the initial stages of the innovation cycle. Indirect methods are used in the process of concept realization, namely, at the stages of pilot production and prototypes commercialization with entry to the market. They, as a rule, have a stimulating character both for the producers and for the product consumers [8-10]. After the default, there was a sharp decline in investment attractiveness for many industries in the Ural region. It should be noted that the inflow of foreign investments in the forestry sector sharply decreased due to the long-term crisis, and in some structures it practically ceased. In certain periods of time investment in fixed assets was made only from our own sources of financing.

The establishment of additional governmental structures in the area also provides significant support. Information support of innovative activities, as well as the pricing and preferential taxation policy can become a priority development direction.

\section{Conclusions}

The improvement of environmental legislation, the system of environmental restrictions and regulation of environmental management regimes are most demanded. Within the framework of this direction, strategies for the sustainable development of the Russian Federation have been developed in the format of the mid-term and long-term Program (1997-2005, 2005-2010, and 2010-2030).

Currently, a draft Program for the development of the forestry sector of the economy up to 2030 has been designed. Certainly, the directions of environmental policy are significant, in demand and can be applied to the forestry sector. There is a need for essential support from the state and municipal authorities in the framework of re-equipment and operation of waste-free production facilities with resource-saving technologies being provided. Particular attention should be paid to the formation of a goal-setting system and the effectiveness of forest management rational development, "economic bonuses" being used as motives and incentives.

\section{References}

1. G. P. Butko, Forest Bulletin. Forestry Bulletin, 24(5), 66

2. A. P. Petrov, Sustainable forest management, 3(62), 5 (2020)

3. K. G. Skripkin, Economic efficiency of information systems, 217 (2020)

4. Ya. P. Silin, E. G. Animitsa, N. V. Novikova, The economy of the region, 12(3), 714 (2016)

5. N. Yu. Kruglova, A. Yu. Edinak, A.V. Ustyuzhanina, Management in Russia and abroad, 6, 56 (2019)

6. Order of the Ministry of natural resources and ecology of the Russian Federation of 13.09.2016 No. 474 «on approval Of the rules of wood harvesting and features of wood harvesting in forest areas, forest parks specified in article 23 of the Forest code of the Russian Federation», http://docs.cntd.ru/

7. The order of Ministry of Russia from 15.01.2019 N 10 "On approval of the order of conducting state forest register and modification of the List, forms and procedure of preparation of documents on the basis of which the entering documented information 
into the state forest register and its change, approved by the Ministry of Russia dated 11 November 2013 N 496", http://rosleshoz.gov.ru/

8. G. P. Butko, Y. V. Savchenko, L. A. Ramenskaya, Fundamentals of enterprise innovation management, 182 (2013)

9. G. P. Butko, P. A. Porotnikov, Managing the competitiveness of timber industry enterprises based on a system of marketing tools, 166 (2016)

10. M. A. Menshikova, G. P. Butko, A. N. Khatsenko, E. B. Goncharova, Bulletin of the Altai Academy of Economics and law, 8(2), 144 (2020)

11. S. V. Makar, Sustainable Forest management, 3(62), 13 (2020)

12. S. Medvedev, A. Mokhirev, T. Rjabova, M. Pozdnyakova, M. Zyryanov, The Model of Management of the Timber Industry Complex in the Conditions of Sustainable Development. IOP Conf. Series: Materials Science and Engineering, 753, 082003 (2020)

13. S. S. Kirillova, Transformation of the structure of the timber industry complex on thepath to new industrialization, IOP Conf. Ser.: Earth Environ. Sci., 392, 012061 (2019) 